\title{
Utilization of Fermented Rice Straw for Bali Cow Feed in the Sari Lestari Livestock Farmer Group
}

\author{
Ni Made Ayu Gemuh Rasa Astiti, Ni Ketut Sri Rukmini, Anak Agung Sagung Putri Risa \\ Andriani \\ \{ayugemuh@gmail.com\} \\ Warmadewa University, Bali, Indonesia
}

\begin{abstract}
PKM activities in Livestock Farmer Groups are carried out in Sembung Village, Mengwi, Badung, precisely in Sari Lestari livestock farmer groups. This research aims to provide an understanding of partners in applying fermented straw feed technology to cow livestock business. Participants were given theoretical knowledge and direct practice regarding the application of fermented straw feed technology. The output targets ensure that partners receive, carry out and have the ability to apply efficient, effective and practical straw feed technology to cows and their impact on improving their development, growth and appearance. The method used to achieve these objectives is training in business and production management, as well as making fermented straw feed (silage). These activities are carried out to efficiently and safely increase businesses by optimizing land use, with local resources used to maximize the internal and regional potential of partners in manufacturing, natural feed and silage. In realizing the achievement of program targets, in addition to training, various practices are simultaneously by partners in accordance with the planned stages guided by field staff and the implementation team and involving students that are first given the ability according to the theme of the program. In practice or program implementation, partners make animal feed in the form of silage with the principle of cost efficiency. Therefore, it is expected that they form and create benefits for economic growth and the creation of new jobs as well as make Sembung Village, safe and inexpensive in order to support government programs on organic and environmentally friendly agriculture (Go-Organic).
\end{abstract}

Keywords : Bali Mains Cow, Fermented Straw, Sembung Village.

\section{Pendahuluan}

Pakan berupa hijauan ternak merupakan pakan utama (60\%) pada ternak Ruminansia dan $40 \%$ berupa konsentrat. Namun fakta di lapangan yang dialami oleh peternak adalah ketersediaan hijauan makanan ternak sangat sulit diperoleh pada musim kemarau yang ratarata selama 5 bulan dalam setahun.Mengatasi permasalahan sulitnya ketersediaan hijauan makanan ternak pada saat musim kemarau adalah dengan memanfaatkan jerami padi sebagai alternatif mengganti hijauan makanan ternak. Namun jerami padi yang merupakan salah satu 
limbah hasil pertanian yang potensial sebagai alternatif pengganti hijauan makanan ternak memiliki nilai kecernaan dan kandungan gizi (terutama protein) sangat rendah yaitu 3-5\% dan kurang disukasi ternak (Fatmawati, 2005). Beberapa cara telah dilakukan untuk meningkatkan nilai cerna dan gizi dari jerami. Salah satunya dengan cara melakukan proses fermentasi (Soeryono et.al., 2004), dengan fermentasi jerami ini, ketersediaan pakan dimusim kemarau bisa teratasi, dimana di desa Sembung pada saat panen padi banyak jerami padi yang dibakar sehingga menimbulkan polusi udara dan akan berakibat terhadap kesehatan manusia akan terganggu. Ada teknologi yang lebih efisien, praktis dan mudah dilakukan dalam memanfaatkan jerami sebagai hijauan makanan ternak dengan teknologi fermentasi jerami, sehingga disaat panen jerami tidak dibakar dan jerami yang terfermentasi ini bisa digunakan dan disimpan berbulan-bulan. peternak bisa menyimpan jerami yang terfermentasi untuk menghadapi musim kemarau, sehingga tidak kekurangan pakan dimusim kemarau.

Berdasarkan hal tersebut diatas, kegiatan PKM yang didanai dari Hibah Institusi Universitas Warmadewa ini diharapkan agar kelompok mitra dan masyarakat sekitarnya akan memiliki kemampuan dan ketrampilan dalam menerapkan teknologi pakan jerami terfermentasi

Tujuan dari pengabdian kepada masyarakat ini adalah memberikan transfer teknologi tepat guna yang mudah dilakukan oleh petani ternak dan memberikan pengetahuan cara beternak sapi yang ramah lingkungan.

Manfaat dari penelitian ini adalah sebagai berikut :

a. Pihak Peternak

Kelompok tani ternak mampu memanfaatkan limbah pertanian khususnya jerami padi untuk pakan ternak yang efisien, efektif dan praktis pada saat kekurangan hijauan pakan ternak terutama pada musim kemarau.

b. Pihak Desa Pekraman

Dengan pemanfaatan jerami padi sebagai pakan ternak sehingga tidak akan mencemari lingkungan sekitarnya terutama pada saat panen raya yang biasanya dibakar atau dibuang begitu saja.

c. Pihak Institusi

Suatu kewajiban bagi perguruan tinggi untuk mengamalkan Tri Dharma Perguruan Tinggi, salah satunya adalah pengabdian kepada masyarakat sehingga melalui pengabdian ini diharapkan ada hubungan yang baik dan saling menguntungkan kedua belah pihak. Selain itu, kegiatan Institusi yang terjun langsung ke lapangan akan membuat keberadaan institusi semakin diketahui oleh masyarakat.

\section{Metode Pemecahan Masalah}

Kelompok terdiri dari 20 orang peternak yang masing-masing memiliki 1 ekor sapi induk yang dipelihara dalam 1 kandang koloni. Namun permasalahan yang dihadapi kelompk mitra adalah sulitnya hijauan pakan ternak pada saat musim kemarau serta banyaknya jerami padi yang dibakar agar lahan cepat bisa digunakan menanam lagi, sehingga menimbulkan polusi udara yang mengancam kesehatan manusia.

Metode yang digunakan dalam pelaksanaan kegiatan Pengabdian Kepada Masyarakat ini adalah :

a. Metode wawancara dan diskusi untuk dapat mengetahui permasalahan yang dialami mitra. 
b. Metode tatap muka dan memberikan ceramah agar mitra mendapatkan pengetahuan mengenai teknologi pakan jerami terfermentasi serta bahayanya asap hasil pembakaran jerami bagi kesehatan manusia.

c. Praktek langsung yang dipandu oleh instruktur yang berkompeten dibidangnya

d. Mitra terlebih dahulu diberikan materi yang telah disiapkan dalam bentuk leaflet serta materi penunjang mengenai cara beternak sapi yang baik dan peternakan yang ramah lingkungan.

e. Penyerahan peralatan dan bahan yang disumbangkan kepada mitra untuk mendukung kegiatan yang dilaksanakan.

f. Melakukan pendampingan dan monitoring secara periodik selama proses pembuatan serta mengevaluasi hasil setiap bulan.

\section{Hasil Kegiatan}

Setelah melakukan beberapa kali pertemuan dengan mitra, maka disepakatilah jadwal kegiatan yang dilaksanakan. Mitra mengajukan beberapa jadwal kegiatan yang disesuaikan dengan aktivitasnya, sehingga pelatihan tidak mengganggu kegiatan dari mitra. Pelaksanaan kegiatan Pengabdian Masyarakat Pemanfaatan Jerami Padi Terfermentasi untuk Pakan Ternak Sapi Bali di Kelompok ternak Sari Lestari di Desa Sembung Mengwi Badung dilakukan dalam beberapa tahap. Hasil kegiatan PKM dari tahapan pelaksanaan kegiatan yang telah dilaksanakan dapat digambarkan sebagai berikut :

Dalam kegiatan ini tim memberikan penjelasan tentang pemanfaatan jerami padi sebagai limbah pertanian yang bisa dimanfaatkan untuk pakan ternak serta menambah nilai gizi dari jerami bila difermentasi, pemanfaatan Jerami padi yang terfermentasi untuk pakan sapi disaat musim kemarau, agar jerami pada saat panen raya tidak dibakar yang berakibat menimbulkan polusi udara yang berefek terhadap terganggunya pernafasan manusia. Jerami yang di fermentasi dengan EM4. Untuk kegiatan ceramah ini team menyediakan modul pelatihan yang berisi materi-materi dari ceramah. Dengan cara seperti ini mitra dapat pemahaman mengenai materi ceramah. Setelah melaksanakan pelatihan secara teori, maka dilanjutkan dengan pengenalan bahan-bahan untuk memperlancar kegiatan pelatihan. Selanjutnya penyerahan alat dan bahan untuk memperlancar kegiatan pelatihan. Tahapan berikutnya pelatihan mengenai pemanfaatan jerami padi terfermentasi dengan menggunakan EM4 sebagai permentor.

Respon mitra/kelompok tani ternak sangat tinggi karena selain praktek juga dilaksanakan tanya jawab/diskusi serta hasil fermentasi jerami diberikan langsung kepada ternak. Serta ternak mau memakannya, sehingga disaat musim kemarau peternak mempunyai cadangan pakan ternak karena jerami terfermentasi bisa disimpan berbulan-bulan, serta tidak ada lagi yang membakar jerami disaat musim panen padi. Melihat hal tersebut peternak menjadi termotivasi untuk memanfaatkan teknologi ini karena efisiensi, efektif dan praktis

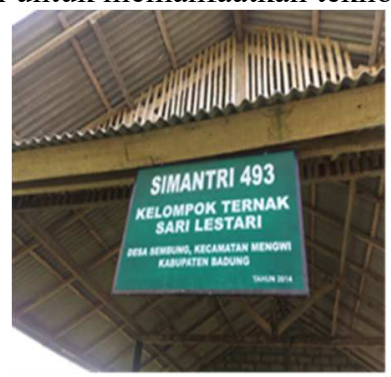

Gambar 1. Papan Nama Mitra

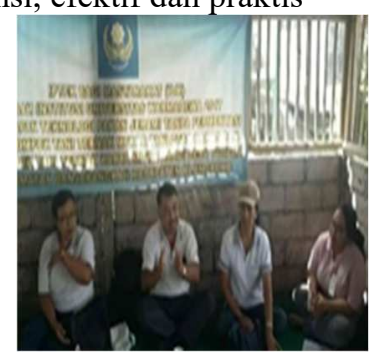

Gambar 2. Pemberian Materi Fermentasi 


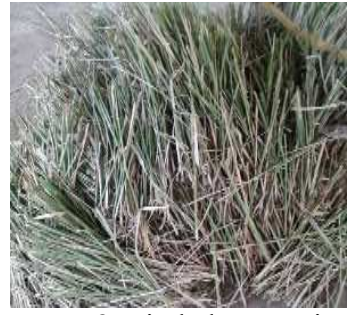

Gambar 3. Limbah Jerami Padi

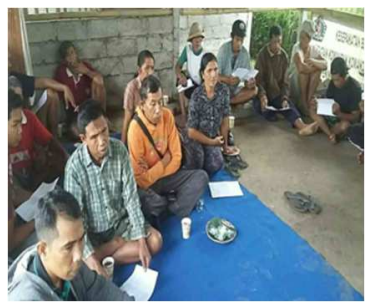

Gambar 5. Peternak Mendengarkan Ceramah Bahayanya Asap Pembakaran Terhadap Kesehatan.

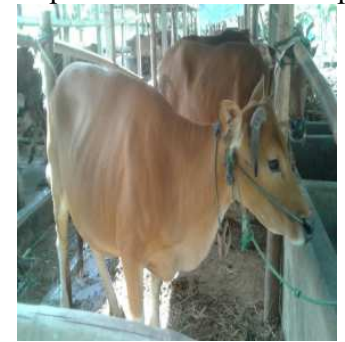

Gambar 7. Sapi Milik Mitra.

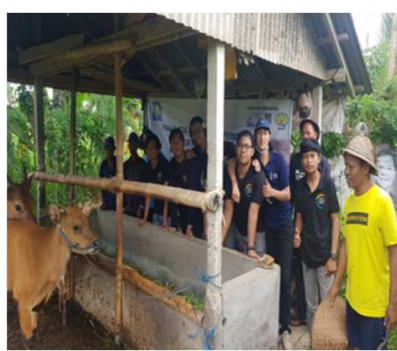

Gambar 9. Pemberian Jerami Terfermentasi

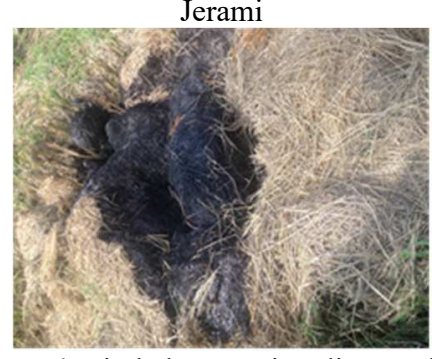

Gambar 4. Limbah Jerami Padi yang dibakar

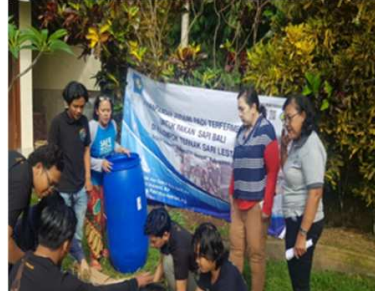

Gambar 6. Praktek Pembuatan Jerami Padi Terfermentasi

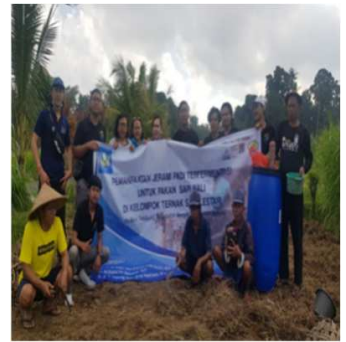

Gambar 8. Penyerahan Alat dan Bahan.

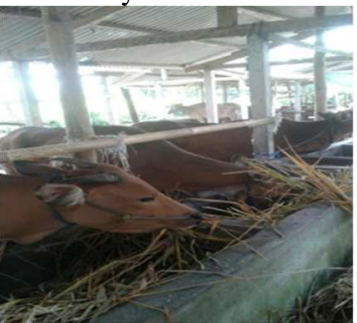

Gambar 10 . Sapi Dengan Lahapnya memakan Jerami Terfermentasi

Dengan adanya fakta-fakta tersebut diatas secara langsung dilihat hasilnya oleh kelompok tani maka mitra beserta anggotanya lebih semangat dan termotivasi untuk menerapkan teknologi ini karena sederhana dan mudah dilakukan oleh petani ternak. Dengan adanya faktafakta tersebut dan secara langsung dilihat hasilnya oleh kelompok tani ternak, maka mitra beserta anggotanya lebih semangat dan termotivasi untuk menerapkan teknologi ini. 


\section{Kesimpulan}

Dari kegiatan yang telah dilaksanakan maka dapat diambil kesimpulan sebagai berikut.

1. Kegiatan pemanfaatan jerami padi terfermentasi dapat berlangsung dengan baik.

2. Kelompok mitra mengetahui, memahami dan menguasai teknologi pembuatan pakan jerami terfermentasi.

3. Pemberian pakan jerami padi terfermentasi dapat meningkatkan kandungan gizi jerami sehingga performance ternak menjadi lebih baik.

4. Berkurangnya pembakaran jerami padi.

\section{References}

[1] Astiti, NMAGR; Rukmini, Ni Ketut Sri dan Ni Ketut Mardewi. 2018. Teknik Budidaya Sapi Bali di Desa Selat Badung. Laporan PKM Institusi Universitas Warmadewa Denpasar.

[2] Anonimous. 2001. Pengawetan Hijauan Untuk Pakan Ternak (Silage). Proyek Peningkatan Teknologi Sapi Perah. Direktorat Jendral Peternakan. Dinas Peternakan Provinsi Jawa Barat. JICA Japan. Jawa Barat.

[3] .Direktorat Jenderal Peternakan. 1982.Inventarisasi Limbah Pertanian Jawa dan Bali Fakultas Peternakan UGM dan Dikrektorat Bina Produksi. Dirjen Peternakan

[4] Fatmawati, 2005. Komposisi Kimia jerami Padi. Fakultas Peternakan Universitas Andalas.

[5] Marhadi, 2009. Potensi Fermentasi Jerami Padi Sebagai Sumber Pakan Untuk Usaha Penggemukan Sapi Potong. Tersedia pada ; http/mahardi.nutrisi06.blogspot.com/2009/05/jerami. Diakses pada tanggal 18 Oktober 2017

[6] Profil Kemlompok Tani Ternak Sari Lestari. 2018. Desa Sembung. Kecamatan Mengwi. Kabupaten Badung.

[7] Sutapa, I G D dan I N. Sutadnya, 2016. Jurnal Lingkungan Wicaksana. Lembaga Penelitian Universitas Warmadewa. Denpasar.

[8] Soeryono,M., M.D. Arebui, Soedomo, dan H. Hartadi. 2004. Penggunaan Pleurotos Sp. Untuk Meningkatkan Nilai Nutrisi Jerami Padi sebagai Pakan Domba. Pros. Pertemuan Ilmiah Penelitian Domba dan Kambing di Indonesia. Puslitbangnak. Bogor 